ape. The presence of such a form in these beds on one hand, and of early palæolithic cultures in the North Indian Pleistocene on the other, inspires the not too remote hope that very primitive hominids may one day be found in this region.

A preliminary note on some of my limnological work has already appeared in NATURE ${ }^{4}$. It is as yet scarcely possible to evaluate the zoogeographical significance of the large collection of fishes and invertebrates brought back. Two points may, however, be briefly noticed.

On the basis of his geomorphological studies, Dr. de Terra has reconstructed ${ }^{\mathbf{1}}$ the Tertiary drainage pattern of the western part of the Tibetan plateau. A number of rivers ran from west to east, one of them occupying the present valley of the Upper Indus. It is difficult to resist the conclusion that a similar pattern extended farther north, the Tarim basin draining into the Hwang-ho. If this hypothesis be accepted, it is possible to give a rational explanation of the distribution of the most characteristic group of Central Asiatic fishes, the Schizothoracinæ. At present this sub-family occurs in at least twelve major river systems and numerous small closed basins. My field studies appear to indicate that the most primitive genus Schizothorax is most abundant in relatively quiet water, while the species found in the most rapid streams belong to the most specialised genera. This is to be expected if we suppose that the subfamily was distributed as the Tertiary drainage pattern suggests, from a centre in the present Karakorum, then a region of comparatively late mature relief, the truly torrenticolous genera such as Dyptichus not evolving until the progressive uplifts had provided a system of suitable habitats for such forms. Further problems of distribution are raised by these and other fish, but it would be out of place to discuss them until the entire collection has been studied by Dr. S. L. Hora.

A second zoogeographical result emerges from a study of the insects of high altitudes. In examining the collection of terrestrial Heteroptera, I have been much impressed by the high proportion of endemic forms; at least half the species are peculiar to the higher parts of the Himalaya and western Tibet. This contrasts strikingly with the situation presented by the Pamirs ${ }^{5}$, where the fauna though richer is much less peculiar. In spite of the intense Quaternary glaciation of the betterknown parts of western Tibet, it seems impossible to avoid the conclusion that a large part of the Tibetan Plateau was unglaciated, forming, as Meinertzhagen ${ }^{6}$ has emphasised, a biological island in which species and even genera were differentiated, and from which the glaciated regions were recolonised.

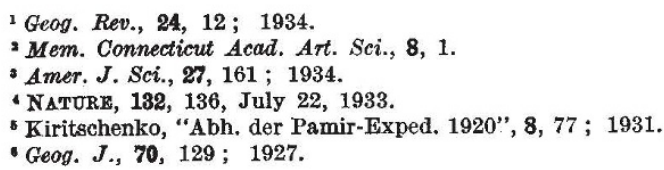

\title{
The Mersey Road Tunnel
}

$\mathrm{T}$ HE tunnel constructed under the Mersey for vehicular traffic between Liverpool and Birkenhead, which was opened by H.M. the King on July 18, is a great engineering construction possessing many interesting features. It is the largest sub-aqueous tunnel yet constructed, its ventilation installation is on an elaborate scale and the architectural treatment of its entrances and buildings have received as much consideration as the construction of the tunnel itself. The consulting engineer for the scheme is Sir Basil Mott, Bt., with whom has been associated Mr. J. A. Brodie, for many years the city engineer of Liverpool, while Mr. H. J. Rowse is the architect of the ventilation buildings. Others who have been called in to advise on various matters include Prof. P. G. H. Boswell, Prof. Douglas Hay and Prof. J. S. Haldane.

A railway tunnel beneath the Mersey has been in use since the 'eighties of last century, but the ever-increasing stream of passengers and vehicles crossing the river by the ferries has long shown the need for further facilities. In 1925 the local authorities obtained from Parliament the Mersey Tunnel Act, and under this was set up the statutory body, the Mersey Tunnel Joint Committee, the controlling authority for the construction of the tunnel. The general plan of the project includes a main tunnel for four lines of traffic from Old Hay- market, Liverpool, to Chester Street, Birkenhead, 3,751 yards long, with two branch tunnels for two lines of traffic, one on either side of the river, bringing the total length of roadway up to 5,064 yards. It is estimated that the tunnel will have a capacity of 4,150 cars per hour moving at 20 m.p.h., the time taken for a vehicle to pass along the tunnel being $6 \frac{1}{2}$ minutes. Side-walks are provided on both sides of the roadways for the staff, but in normal circumstances the tunnel will not be used by pedestrians.

The portion of the tunnel of greatest interest is that beneath the river bed. Here the bottom of the tunnel is $170 \mathrm{ft}$. below high water, while above the top is an average thickness of $\mathbf{3 0 - 3 5} \mathrm{ft}$. of rock, gravel and clay. The rock is red triassic sandstone. Circular in section, this portion of the tunnel has external and internal diameters of $46 \frac{1}{4} \mathrm{ft}$. and $44 \mathrm{ft}$. respectively. It is thus the largest sub-aqueous tunnel in the world, the Rotherhithe Tunnel, London, having a diameter of $30 \mathrm{ft}$. and the Holland Vehicular Tunnels, New York, a diameter of $29 \frac{1}{2} \mathrm{ft}$.

Begun in 1925, two pilot headings were first driven from each of the two shafts sunk on each side of the river and the workings met almost exactly in the middle of the river bed on April 3, 1928. The divergence of line, length and level was very slight. These pilot headings were then 
progressively enlarged, and stage by stage the tunnel was lined with cast-iron segments each weighing about a ton, placed in position by a special erecting machine. All segments were machined at the joints and watertightness was ensured by the use of lead caulking. The $4 \frac{1}{2}$ in. space between the back of the circular lining and the rock was then filled in with stone and a grout of cement and sand. Later on, the internal spaces of the segment were filled with concrete and finally finished with creamcoloured gypsum plaster sprayed with a transparent polish.

The roadway of reinforced concrete is built on a line a little below the horizontal diameter of the tunnel and is supported on two longitudinal reinforced concrete walls $21 \mathrm{ft}$. apart. These walls divide the lower portion of the tunnel into three sections, the centre one of which may perhaps at some future time be used for single-deck tramcars, and two side passages, approximately triangular in section, which will be used for the supply of fresh air. The air will find its way into the tunnel through longitudinal ducts on either side of the roadway at the level of the kerb. Provision is also made for electric cables, water mains and drainage pipes.

The ventilation system was designed after fullscale experiments on a length of $1,000 \mathrm{ft}$. of finished tunnel using full-sized fans. These experiments were supervised by physiologists and ventilation experts, and they were also directed to ascertain which system would give the best results in the event of a serious petrol fire. As a basis, a traffic flow of 3,000,000 vehicles a year was assumed, and the plant as installed will ensure that, under normal conditions, the proportion of carbon monoxide will not exceed $2 \frac{1}{2}$ parts in 10,000 parts of air, or 4 parts in 10,000 under extreme peak-load conditions. There are six ventilation buildings, three on each side of the river, with supply and exhaust fans, the whole plant including 30 fans with a total capacity of $10,000,000 \mathrm{cub}$. ft. of air per minute, each section of the plant being duplicated. Each ventilation building consists of a steel-framed structure with a central tower. In each case, fresh air will be drawn through intakes in the roof of the building by the supply fans and discharged into the air ducts, while the foul air will be drawn by the exhaust fans from the upper part of the tunnel and discharged up the central tower. All the fans are electrically driven and are remotely-controlled from the ventilation building at George's Dock, Liverpool, which will house the administration offices. The many other interesting features of this great undertaking include the pumping plant for dealing with water which may find its way into the tunnel, a system of lighting which does away with the necessity of cars switching on their head or side lights, fire and telephone stations and signals for instructing drivers to stop their engines. The cost of the whole scheme, including purchase of the land, has been about $£ 7,000,000$, towards which the Government made a grant of $£ 2,500,000$ from the Road Fund. Loans have been raised by the Corporations of Liverpool and Birkenhead which will be paid back out of the tolls and the rates. A fully illustrated account of this important work was given in Engineering of January 19, February 16 and March 16.

\section{International Council of Scientific Unions Meeting at Brussels}

1 HE International Council of Scientific Unions (formerly the International Research Council) held its first triennial meeting, since its new statutes were adopted, on July 8-13 at Brussels. The general assembly of delegates met at the Palais des Académies, Brussels, and elected Dr. N. E. Nörlund, director of the Geodetic Institute, and Rector of the University of Copenhagen, president for the period 1934-37; General J. F. Bourgeois, of the Academy of Sciences, Paris, and Marchese Marconi, president of the National Research Council of Italy, were elected vicepresidents. Dr. Pelseneer and Dr. Went remain members of the executive committee, and Sir Henry Lyons the general secretary.

At this meeting for the first time, the International Unions of Astronomy, Geodesy and Geophysics, Chemistry, Scientific Radio, Physics, Geography and the Biological Sciences, attended as members of the Council, and communicated very interesting accounts of their activities in their respective scientific fields of work during the past three years.

For the first time also, addresses were given on scientific matters of general interest, and these included, on this occasion, one by Dr. D. la Cour on the International Polar Year, 1932-33, its aims, methods and some preliminary results; another by General G. Perrier, on recent international determinations of longitude; while Dr. E. P. Hubble spoke on the exploration of space, and Prof. H. R. Kruyt on electricity and hydration with colloids.

The International Committee on the Relationship between Solar and Terrestrial Phenomena was reappointed, and another on instruments and methods met to arrange its future procedure.

The following motion, put forward by the Royal Academy of Sciences, Amsterdam, was unanimously adopted by the General Assembly:

"The International Council of Scientific Unions, being aware of the fact that the present economic and political difficulties have brought humanity face to face with a number of the most complicated and dangerous problems and threaten to erect a system of barriers between various nations, expresses its deep faith that ultimately a way will be found leading towards a more harmonious economic structure, and wishes to stress the importance of maintaining by all means international co-operation in the 